\title{
Malthusian Dynamism and the Rise of Europe: Make War, Not Love
}

\author{
By Nico Voigtländer And Hans-JoAChim Voth*
}

Malthusian conditions are a byword for stagnation. We argue that this view is wrong. Europe's relative riches in 1700 are best understood as the result of Malthusian forces favoring high per capita output. Favorable shifts in mortality and fertility schedules were responsible. Incomes between 1300 and 1800 rose because of two related but distinct European "inventions"- a peculiar marriage pattern and a specific mortality regime. These interacted with the political, social, and economic environment in such a way as to make higher equilibrium incomes sustainable.

Even in a simple Malthusian world, incomes can change, but only in the short run. They did so markedly after the Black Death. As landlabor ratios rose in an economy subject to strong declining marginal returns, workers became more productive. Income after 1350 roseperhaps by as much as a factor of three (Henry Phelps-Brown and Sheila V. Hopkins 1981; Gregory Clark 2005). In a Malthusian world where land-labor ratios are a prime determinant of income levels, such riches should not last. Birth rates increase; death rates fall. Population rises in response to the windfall. Eventually, the economy returns to the previous equilibrium, with identical wages and population size. ${ }^{1}$

\footnotetext{
* Voigtländer: Anderson School of Management, University of California-Los Angeles, 110 Westwood Plaza, Los Angeles, CA 90095 (e-mail: nico.v@anderson.ucla. edu); Voth: Department of Economics, Universitat Pompeu Fabra, c/Ramon Trias Fargas 25-27, E-08005 Barcelona, Spain (e-mail: voth@mit.edu). We are grateful to Steve Broadberry, Greg Clark, Nick Crafts, Matthias Doepke, Kiminori Matsuyama, Joel Mokyr, and David Weil for helpful comments and suggestions. We thank Morgan Kelly for sharing unpublished results with us.

${ }^{1}$ Quamrul Ashraf and Oded Galor (2008) provide crosssectional evidence for the predictions of the Malthusian model. They show that population density until 1500 depends positively on soil fertility and on a proxy for agricultural productivity (years since the Neolithic transition), while per capita income is independent of these indicators.
}

The logic of the Malthusian world leads Clark (2007) to conclude that Englishmen in 1800 were as poor as their ancestors on the African savannah. Yet, Europe in the early modern period was unusually rich, despite abundant evidence that hard times could drive up death rates (Malthus's "positive check") and reduce birth rates. ${ }^{2}$ The emergence of such differences in income should be puzzling in a world where Malthusian forces are strong, and technological progress as well as institutional improvements were slow. Western Europe in 1700 already was at least twice as urbanized as any other part of the globe. Incomes probably towered over those in other areas, recent arguments by the "California School" that emphasizes the productivity of the Yangtze area not withstanding. ${ }^{3}$

This paper argues that Malthusian regimes are capable of sustained changes in per capita incomes. Shifting mortality and fertility schedules can lead to different steady-state income levels, with long periods of growth during the transition. ${ }^{4}$ Europe checked the downward pressure on wages through late marriage, which reduced fertility, and a mortality regime that combined high death rates with high incomes. We argue that both emerged as a result of the Black Death.

\section{Malthusian Basics}

The economy produces a homogenous goodfood-using a Cobb-Douglas technology with labor $(L)$ and land $(T)$ as inputs. Per capita income is given by

\footnotetext{
2 This may also have facilitated the transition to selfsustaining growth after 1800 , as we argue in Voigtländer and Voth (2006)

${ }^{3}$ Kenneth Pomeranz (2000); Jack Goldstone (2003). Recent work by Stephen N. Broadberry and Bishnupriya Gupta (2005) suggests that income differences remained substantial

${ }^{4}$ This argument is also explored in Joel Mokyr and Voth (2009).
} 


$$
y=A\left(\frac{T}{L}\right)^{\alpha},
$$

where $\alpha$ is the land share of income. Land is in fixed supply. In the short run, per capita income grows in total factor productivity (TFP) $(A)$ and decreases in population. Population growth $\gamma_{L}$, in turn, responds to nutrition, and is given by the difference between birth rates $(b)$ and death rates $(d)$. This relationship is captured by

$$
\gamma_{L}=b-d=b_{0}(y / \underline{y})^{\varphi_{b}}-d_{0}(y / \underline{y})^{\varphi_{d}}
$$

where $y$ denotes "subsistence" income, ${ }^{5}$ and $b_{0}\left(d_{0}\right)$ is the birth (death) rate at $y$. We choose $b_{0}=d_{0}=3$ percent. This corresponds to a life expectancy of 33 years. Next, we use $\varphi_{b} \simeq 1.4$ and $\varphi_{d} \simeq-0.5$ as the elasticities of birth and death rates with respect to income, respectively. ${ }^{6}$ Therefore, higher income translates into more births and lower mortality. This relationship is shown by the solid curves in Figure 1.

In the short run, population $L$ is given, and (1) determines per capita income. In the longrun, however, the population dynamics given in (2) pin down the land-labor ratio, which in turn affects $y$. In the absence of technological progress, death rates equal birth rates, and $L$ is constant. The same holds for per capita income. The level at which $y$ stagnates depends on the location of the fertility and mortality schedules, as represented by point $E_{0}$ in Figure 1. A one-time increase in TFP temporarily relieves Malthusian constraints; population can grow. Eventually, the falling land-labor ratio drives wages back to their original level. Per capita income is thus self-equilibrating.

Despite the power of self-equilibrating forces, stagnation at subsistence is not inevitable. In the following, we analyze three mechanisms that can change the long-run income level.

\section{A European Mortality Pattern}

War was the favorite game of princes. It was practiced avidly in early modern Europe.

\footnotetext{
${ }^{5}$ Initially, incomes stagnate at this level. Note, however, that complete starvation need not follow if incomes fall below $y$. Rather, death rates exceed birth rates, and population slowly falls.

${ }^{6}$ Values for $\varphi_{b}$ and $\varphi_{d}$ are from Morgan Kelly (2005). We discuss the choice of parameters in Voigtländer and Voth (2008b).
}

European powers were at war for an average 90 out of every 100 years between 1500 and 1800 (Charles Tilly 1992). How could European powers come to fight each other so frequently? In Voigtländer and Voth (2008b), we argue that the great plague of the fourteenth century is indirectly responsible.

As incomes increased beyond subsistence levels, Europeans everywhere began to buy more than just food. Many income-elastic goods were produced in towns, such as cloth, tableware, cutlery, and shoes. Market transactions were necessary to obtain the cash for these purchases-monetization increased. Importantly, towns offered access to the liquid wealth that princes needed to fund their wars. Residents of cities were also more easily taxed than peasants in the countryside, whose contributions were principally in kind. War, therefore, was a luxury good for rulers in early modern Europe, and one whose availability depended more on the per capita income of citizens than on absolute output. In a highly fragmented political environment, the surge in available funds produced a rapid and sustained rise in the frequency and intensity of warfare.

Military technology in early modern Europe was too primitive to wreak much havoc directly, the horrors of the Thirty Years War not withstanding (John Landers 2003). Armed conflict was deadly, not because of battlefield deaths or direct civilian casualties, but because of diseases spread by troops. The plague itself was brought to Europe as a result of the siege of Kaffa in the Crimea, after the besieging Tartars used catapults to throw the corpses of deceased soldiers over the city walls. Until the nineteenth century, diseases spread in the wake of marching armies were more deadly than the fighting itself. Geographical heterogeneity spelled relative isolation for many populations. Even mild diseases such as influenza could turn into a major cause of death in remote areas.

Passing armies would often requisition seed and livestock, causing peasants to starve. While the destruction that followed was negative for output in the short run, frequent and early deaths were beneficial for the survivors' incomes. ${ }^{7}$

\footnotetext{
${ }^{7}$ The negative shock to agricultural output was not longlasting since the reproduction rates of livestock are high,
} 


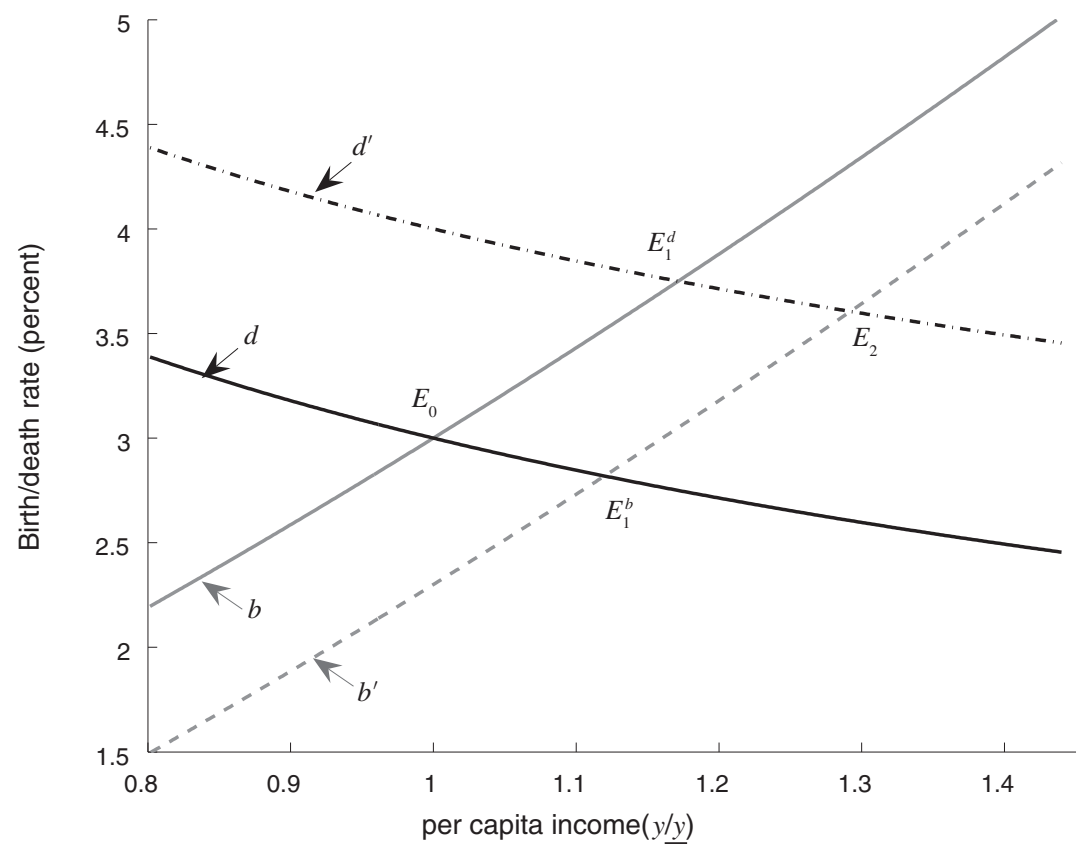

Figure 1. LONG-RUN EQUILIBRIA

Higher post-plague incomes yielded a greater extractable surplus. This was partly used by European kings to fight each other. The upward shift in death rates was reinforced by two auxiliary factors-diseases spread via trade routes, and the unhygienic conditions in early modern European cities.

After 1348-1349, the plague broke out again and again in Europe, before vanishing in the eighteenth century. Epidemics of other diseases, such as typhus and smallpox, were also common. Where they were not spread by troops on the march, they often arrived in the bottoms of merchant ships or on the wagons of traders. The last plague outbreak in Western Europe, in Marseille in 1720, was due to a merchant vessel bringing silk and other goods from the Levant. Trade increased as a result of the higher incomes after the Black Death. These higher incomes went hand-in-hand with higher death rates, thus producing a self-reinforcing effect in a Malthusian setting.

European cities were famously unhealthy. Before 1850 , most of them would have disappeared

and because land left fallow will be more productive once it is brought under the plough. had it not been for continuous in-migration. Life expectancy in London, 1580-1799, was short (27 years, compared to 35-38 years in Britain as a whole). ${ }^{8}$ In part, cultural practices were to blame. While Europeans dumped their chamber-pots out of the window, Chinese cities ferried human excrement to the countryside, where it was used as fertilizer. Higher incomes meant that more meat was consumed in Europe. The proximity of animals such as chickens and pigs spread disease (Jared Diamond 1997). Finally, due to frequent warfare, many European cities were surrounded by massive fortifications. As population size increased, densities had to rise-expansion outside the city walls was dangerous, and moving Italian-style fortifications much too costly. High densities, polluted water sources, and unhygienic cultural practices conspired to raise death rates in European cities. As per capita incomes and agricultural productivity increased after 1349 , urbanization rates went up. This itself raised death rates in the aggregate.

In combination, war, trade, and city mortality raised European mortality substantially. As

\footnotetext{
${ }^{8}$ Landers (1993); E. Anthony Wrigley et al. (1997).
} 
Malthus (1826) famously observed, "war and contention," "unwholesome trades and manufactories," and "great and pestilent cities" with a "prejudicial effect on the human constitution" can act as important brakes on population pressure. In Voigtländer and Voth (2008b), we show that these three factors raise aggregate death rates by more than 1 percent (in addition to the 3 percent background mortality). All of these factors were directly or indirectly related to rising incomes-as a source of financing for war, or as a cause for demand for trade and urban products. In turn, they facilitated the perpetuation of higher incomes, by relieving downward pressure on the land-labor ratio. Because the death schedule in early modern Europe shifted outward, incomes could be permanently higher than they had been before the Black Death. This is shown as an upward shift of the death schedule in Figure 1 from $d$ to $d^{\prime}$. The corresponding equilibrium is $E_{1}^{d}$, which combines higher per capita income levels with lower population. Under plausible assumptions, this effect alone raises per capita income by up to 20 percent, thus contributing importantly to the precocious rise in European per capita output.

\section{The European Marriage Pattern}

Fertility restriction was not uncommon in pre-modern societies. Chinese families used infanticide, and had low rates of marital fertility. However, west of a line from St. Petersburg to Trieste, Europeans practiced a unique and peculiar form of fertility limitation (John Hajnal 1965, 1982). Women did not marry when they became fertile, but markedly later-age at first marriage could be as late as 25 or 28 . Also, a high percentage (up to 15 percent) never married. Once married, however, there was no fertility limitation. Overall, the European marriage pattern (EMP) prevented between a quarter and half of all possible births (Clark 2007). Population pressure was thus reduced. This helped to maintain relatively high per capita incomes (Wrigley 1988).

What caused Europeans to adopt this particular marriage pattern is still unclear. Some theories emphasize inheritance rules, and the North-South divide in fertility within Europe. Others underline the role of labor markets and urbanization in giving women greater bargaining power (Tine de Moor and Jan Luiten van Zanden 2005). The system's origins are hard to pin down. Roman Europe had early and nearuniversal marriages for women. While there is evidence of some women remaining unmarried before 1000, EMP found its full expression only after 1400 (Hajnal 1965, 1982). Religion cannot be the answer-Europe was Christian long before it became a low-fertility area.

Our explanation for EMP adoption focuses on what many young women did before getting married. The vast majority-especially on the lower rungs of society-worked as servants, either in domestic service or in agriculture. Food and lodging were provided free of charge, in exchange for labor services. In addition, servants received a wage in cash. This was mostly saved in the hope of finding a better match in the marriage market. According to estimates by Ann Kussmaul (1981), more than half of all English women and men age 15 to 24 worked as servants during the early modern period-the vast majority of them in agriculture. In particular, women worked as servants in husbandry, milking cows, and tending flocks.

The positive shock to incomes after the Black Death increased demand for the products of pastoral agriculture. While the extent of the rise in meat consumption after 1349 is disputed, the general switch in agricultural production from "corn to horn" (Bruce M. S. Campbell 2000) is not. In addition to the higher demands for meat, production of wool and consumption of cheese and other dairy products surged. These were classic "superior goods" of the period. Pastoral production on average took place in much larger production units. Landlords often converted arable to pastoral production, driving farmers off the land. This is why, in 1516, Thomas More wrote of "man-eating sheep" in his Utopia.

The rise in livestock production was landusing and labor-saving. In particular, it economized on the factor of production that had become particularly expensive after 1349—-male labor. Women could perform many of the tasks in animal husbandry. Because of the year-round labor requirements in pastoral farming, employing servants on year-long or multiyear contracts was convenient. Servants overwhelmingly lived in the households of large landowners, and were obliged to remain unmarried. Thus, the positive demand shock for pastoral products after the Black Death laid the foundations for the emergence of EMP (Voigtländer and Voth 
2008a). For many women, spending an extended period before marriage as servants became a way of life.

Importantly, the institution also worked as a "shock absorber"-in bad times, when wages were low, accumulating savings took longer. Marriages were delayed, and population pressure was reduced. Thus, EMP simultaneously reduced fertility rates overall, and facilitated adjustment to adverse shocks. This is shown by a downward shift of the birth schedule from $b$ to $b^{\prime}$ in Figure 1, leading to the new long-run equilibrium $E_{1}^{b} .{ }^{9}$ The lower bound estimate-a difference of 25 percent between $b$ and $b^{\prime}$-implies a substantial rise in per capita income, exceeding 10 percent.

\section{Technological Progress}

We now turn to an alternative explanationtechnological progress - and show why its role in the initial rise of Europe was probably limited. Suppose that TFP grows at the rate $\gamma_{A}$. Following (1), this implies $\gamma_{y}=\gamma_{A}-\alpha \gamma_{L}$, where population growth $\gamma_{L}$ is given by (2). Higher steadystate per capita income goes hand-in-hand with faster population growth. In Figure 2, per capita income will grow until $\gamma_{A}=\alpha(b-d)$. At this point, TFP increases are offset by the growing population, and per capita income stagnates in the new equilibrium $E_{T F P}$.

We use the same parameter values as before to determine the magnitude of effects. During the early modern period, TFP grew at rates between 0.05 and 0.15 percent per year (Galor 2005). ${ }^{10}$ We assume that technological progress suddenly accelerates such that $\gamma_{A}$ increases from zero in $E_{0}$ to 0.1 percent. In this case, the new long-run equilibrium $E_{T F P}$ involves population growth $\gamma_{L, T F P}=b-d=\gamma_{A} / \alpha=0.25$ percent. ${ }^{11}$ The corresponding increase in long-run per capita income is less than 5 percent. $^{12}$

\footnotetext{
${ }^{9}$ Strictly speaking, the EMP involves rotating the birth schedule, as well as a downward shift. Voigtländer and Voth (2008a) show that both effects emerge endogenously in response to product and labor market conditions after the Black Death.

${ }^{10}$ Low TFP growth apparently existed side-by-side with numerous important inventions (Mokyr 1990).

${ }^{11}$ This assumes a labor share in agricultural income $(1-\alpha)$ of 0.6 .

${ }^{12}$ To derive this number, we use a linear approximation of (2) around the equilibrium without technological change
}

How fast would technology have to grow to explain rising incomes in early modern Europe? Based on Angus Maddison's (2001) figures, we derive a lower bound of per capita output increases, focusing only on the period 1500-1700. Over these two centuries, European per capita income increased by 30 percent. If this effect were driven solely by technological improvements, the rate of population growth in 1700 would have to be at least 1.7 percent (corresponding to equilibrium $E_{T F P}^{\prime}$ in Figure 2). ${ }^{13}$ To sustain per capita incomes at 30 percent above $E_{L}$, TFP would have to grow at $\gamma_{A}^{\prime}=\alpha \gamma_{L, T F P}^{\prime} \simeq$ 0.7 percent p.a. Technological progress of this magnitude was not observed before the second half of the nineteenth century (N. F. R. Crafts and C. Knick Harley 1992; Pol Antràs and Voth 2003). If we assessed the strength of Malthusian responses accurately, improvements in the stock of useful knowledge and of organizational capacity were not fast enough to contribute to rising incomes significantly.

\section{Conclusion}

Europe's early modern riches were largely a gift of the dead, and of the unborn. ${ }^{14}$ Europeans died early and married little, and late, given how high incomes were relative to the rest of the world. We argue that these peculiar features evolved in response to a massive, negative shock to population-the great plague of the fourteenth century. It killed between a third and half of all Europeans; land-labor ratios increased. Higher production per head created fresh demand for the "luxury products" of the daymutton and beef, woolen cloth and city goods. As incomes surged, agriculture switched from "corn to horn," and cities swelled in size. The rise of pastoral production encouraged the emergence of the European marriage pattern. Women came to delay marriage long after first menarche because demand for their labor was now strong. This kept population pressure in check.

\footnotetext{
$\left(y_{0}=y\right.$ and $\left.\gamma_{L, 0}=0\right)$. This yields $\gamma_{L, T F P}=\left(\varphi_{b}-\varphi_{d}\right) b_{0}\left(y_{T F P}\right.$ $\left.-y_{0}\right) \bar{y}=(1.4+0.5) \times 3$ percent $\times\left(y_{T F P} / \underline{y}-1\right)=0.25$ percent. Rearranging, we obtain $y_{T F P} / y=1 . \overline{0} 44$.

13 This follows from the same argument as above, which implies $\gamma_{L, T F P}^{\prime}=(1.4+0.5) \times 3$ percent $\times 0.3=$ 1.7 percent. This number is ten times larger than the actual increase in European population between 1500 and 1700 (Maddison 2001).

${ }^{14}$ With apologies to Alwyn Young (2005).
} 


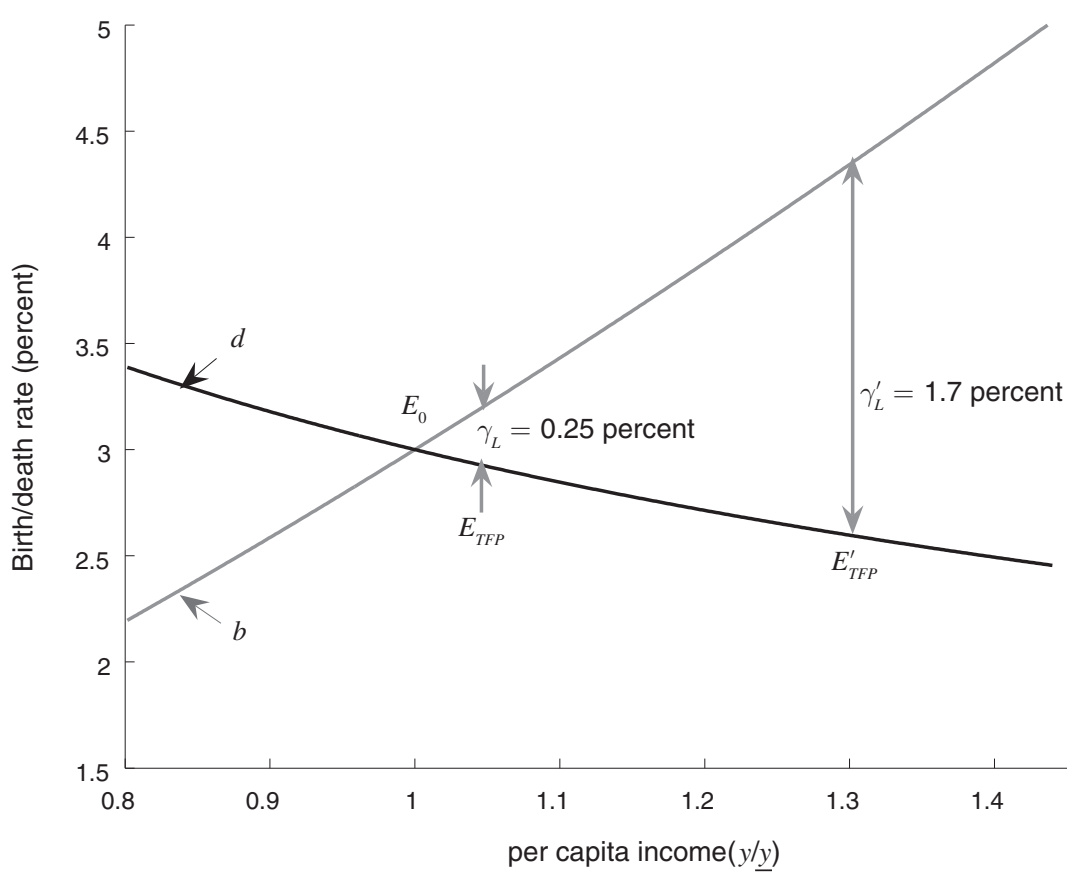

Figure 2. Ongoing Technological Change

Rapid gains in urbanization also increased death rates, since European cities were unusually unhealthy. With city growth, trade increased, spreading disease. The same was true of wars, which Europeans fought with singularly high frequency after 1400. Greater expropriable surpluses and growing city wealth paid for the upsurge in fighting. In combination, urbanization, trade, and war produced an upward shift of the death schedule. This also reduced downward pressure on the land-labor ratio. A combination of both fertility and mortality changes in the aftermath of the Black Death leads to equilibrium $E_{2}$ in Figure 1. It shows how lower fertility and higher mortality ensured that European wage rates did not return to their low, prePlague level. For plausible parameter values, our approach can explain a rise of per capita income of 30 percent-almost exactly the increase observed in Europe, 1500-1700, overall.

Even in a Malthusian world, Ricardo's "Iron Law of Wages" need not hold. While equilibrating Malthusian forces may be strong, ensuring that a steady state is reached quickly, a wide range of equilibrium wage rates can be maintained indefinitely if birth and death rates themselves shift. We have argued that major shocks, such as the Black Death, produced such shifts. In our view, they were instrumental in the rise of European incomes far above subsistence during the early modern period-long before technological change became rapid.

\section{REFERENCES}

Antràs, Pol, and Hans-Joachim Voth. 2003. "Factor Prices and Productivity Growth During the British Industrial Revolution." Explorations in Economic History, 40(1): 52-77.

Ashraf, Quamrul, and Oded Galor. 2008. "Dynamics and Stagnation in the Malthusain Epoch: Theory and Evidence." Brown University Department of Economics Working Paper 2008-14.

Broadberry, Stephen N., and Bishnupriya Gupta. 2005. "The Early Modern Great Divergence: Wages, Prices and Economic Development in Europe and Asia, 1500-1800." Center for Economic Policy Research Discussion Paper 4947.

Campbell, Bruce M. S. 2000. English Seigniorial Agriculture, 1250-1450. Cambridge: Cambridge University Press. 
Clark, Gregory. 2005. "The Condition of the Working Class in England, 1209-2004." Journal of Political Economy, 113(6): 1307-40.

Clark, Gregory. 2007. A Farewell to Alms: A Brief Economic History of the World. Princeton, NJ: Princeton University Press.

Crafts, N. F. R., and C. Knick Harley. 1992. "Output Growth and the British Industrial Revolution: A Restatement of the Crafts-Harley View." Economic History Review, 45(4): 703-30.

de Moor, Tine, and Jan Luiten van Zanden. 2005. "Girlpower. The European Marriage Pattern and Labor Markets in the North Sea Region in the Late Medieval and Early Modern Period." Unpublished.

Diamond, Jared. 1997. Guns, Germs, and Steel: The Fates of Human Society. New York: Norton.

Galor, Oded. 2005. "From Stagnation to Growth: Unified Growth Theory." In Handbook of Economic Growth, ed. Philippe Aghion and Steven Durlauf, 171-293. Amsterdam: Elsevier North-Holland.

Goldstone, Jack. 2003. "Feeding the People, Starving the State: China's Agricultural Revolution of the 17th and 18th Centuries." Paper presented at the Global Economic History Network Conference, London.

Hajnal, John. 1965. "European Marriage Pattern in Historical Perspective." In Population in History. Chicago: Aldine Publishing Company.

- Hajnal, John. 1982. "Two Kinds of Preindustrial Household Formation System." Population and Development Review, 8(3): 449-94.

Kelly, Morgan. 2005. "Living Standards and Population Growth: Malthus was Right." Unpublished.

Kussmaul, Ann. 1981. Servants in Husbandry in Early Modern England. Cambridge: Cambridge University Press.

Landers, John. 1993. Death and the Metropolis: Studies in the Demographic History of London, 1670-1830. Cambridge: Cambridge University Press.

Landers,John.2003.TheFieldandtheForge:Population, Production, andPowerin the Pre-Industrial West. Oxford: Oxford University Press.
Maddison, Angus. 2001. The World Economy: A Millennial Perspective. Paris: Organization for Economic Co-operation and Development.

Malthus, Thomas. 1826. An Essay on the Principle of Population. 6th ed. London: John Murray.

Mokyr, Joel. 1990. The Lever of Riches. Oxford: Oxford University Press.

Mokyr, Joel, and Voth, Hans-Joachim. 2009. "Understanding Growth in Early Modern Europe." In Cambridge Economic History of Europe Vol..1, ed. Stephen Broadberry and Kevin O'Rourke. Cambridge: Cambridge University Press.

Phelps-Brown, Henry, and Sheila V. Hopkins. 1981. A Perspective of Wages and Prices. Florence, KY: Routledge.

Pomeranz, Kenneth. 2000. The Great Divergence: China, Europe, and the Making of the Modern World Economy. Princeton, NJ: Princeton University Press.

Tilly, Charles. 1992. Coercion, Capital, and European States, AD 990-1992. Cambridge, MA: Blackwell.

- Voigtländer, Nico, and Hans-Joachim Voth. 2006. "Why England? Demographic Factors, Structural Change and Physical Capital Accumulation during the Industrial Revolution." Journal of Economic Growth, 11(4): 319-61.

Voigtländer, Nico, and Hans-Joachim Voth. 2008a."How the West Invented Fertility Restriction." Unpublished.

Voigtländer, Nico, and Hans-Joachim Voth. 2008b. "The Three Horsemen of Growth: Plague, War and Urbanization in Early Modern Europe." Unpublished.

Wrigley, Edward Anthony. 1988. Continuity, Chance and Change: The Character of the Industrial Revolution in England. Cambridge: Cambridge University Press.

Wrigley, E. Anthony, R. S. Davies, J. E. Oeppen, and R. S. Schofield. 1997. English Population History from Family Reconstitution 1580-1837. Cambridge: Cambridge University Press.

- Young, Alwyn. 2005. "The Gift of the Dying: The Tragedy of Aids and the Welfare of Future African Generations." Quarterly Journal of Economics, 120(2): 423-66. 